УДК 342.9

DOI https://doi.org/10.32844/2618-1258.2019.3-1.20

ГУТЬ Н.Ю.

\title{
КОНЦЕПЦІЇ ВИЗНАЧЕННЯ ФУНКЦІЇ ЯК КАТЕГОРІЇ АДМІНІСТРАТИВНОГО ПРАВА І ПРОЦЕСУ
}

У роботі розкрито основні наукові підходи до визначення поняття «функція» як категорії адміністративного права і процесу. На підставі проведеного аналізу запропоновано виділяти наступні основні підходи до визначення поняття «функція»: 1) функція як призначення, роль кого- чи чого-небудь; 2) функція як робота кого-, чого-небудь, обов'язок, коло діяльності; 3) функція як напрям дії кого- чи чого-небудь; 4) повна відмова від використання цього поняття в наукових джерелах та джерелах права; 5) функція як симбіоз трьох понять «цілі», «засоби» і «результат»; 6) дослідження функцій через застосування постулатів функціонального підходу.

Наголошено, що функціональна єдність цілого як постулат функціонального підходу може бути застосований і при аналізі функцій адміністративного процесу. Адміністративний процес можна розглядати як системне явище, він складається 3 проваджень, стадій, етапів та окремих процесуальних дій. Кожен елемент цієї системи забезпечує ефективне та якісне функціонування адміністративного процесу в цілому. Зроблено висновок, що при аналізі особливостей функцій адміністративного процесу можна використовувати універсальний функціоналізм, як другий постулат функціонального підходу, згідно з яким кожен елемент системи (в нашому випадку вид провадження чи стадія адміністративного судочинства) повинен відповідати тим функціям, які реалізує адміністративний процес в цілому. Наприклад, спрощені позовні провадження не повинні заважати реалізації таких загальних функцій адміністративного процесу як охорона, контроль та захист.

Обгрунтовано, що реалізація функціональної необхідності (як третього постулату функціонального підходу) при визначенні функцій адміністративного процесу проявляється в тому, що адміністративний процес в цілому та окремі його елементи повинні реалізовувати лише ті функції, які дозволяють системі досягати поставлених цілей.

Ключові слова: адміністративний процес, функиія як категорія адміністративного права, наука адміністративного права і процесу, функиії адміністративного прочесу.

The main scientific approaches to defining the concept of "function" as a category of administrative law and process are revealed in the paper. Based on the analysis, it is proposed to identify the following basic approaches to the definition of the concept of "function": 1) function as a function, role of someone; 2) function as the work of someone, something, duty, scope of activity; 3) function as a direction of action of someone; 4) complete rejection of the use of this concept in scientific sources and sources of law; 5) function as a symbiosis of the three concepts of "purpose", "means" and "result"; 6) study of functions through application of postulates of functional approach.

It is emphasized that functional unity of the whole as a postulate of the functional approach can be applied also in the analysis of the functions of the administrative process. The administrative process can be regarded as a systemic phenomenon, it consists of proceedings, stages, stages and individual procedural actions. Each element of this system ensures the efficient and quality functioning of the administrative process as a whole. It is concluded that in the analysis of the peculiarities of the functions of the administrative process it is possible to use universal functionalism, as the second postulate of the

(C) ГУТЬ Н.Ю. - кандидат юридичних наук, доцент кафедри конституційного права (Київський національний університет імені Тараса Шевченка) 
functional approach, according to which every element of the system (in our case, the type of proceedings or the stage of administrative proceedings) must correspond to those functions that are implemented by the administrative process as a whole.

For example, simplified lawsuits should not interfere with the implementation of such general functions of the administrative process as protection, control and protection. It is substantiated that the implementation of a functional necessity (as the third postulate of the functional approach) in defining the functions of an administrative process is manifested in the fact that the administrative process as a whole and its individual elements must implement only those functions that allow the system to achieve its goals.

Key words: administrative process, function as a category of administrative law, science of administrative law and process, functions of administrative process.

Вступ. У науковій літературі існує багато підходів до визначення поняття «функція» по відношенню до державно-правових явищ, а ще більше сфер де воно, іноді безпідставно, використовується. Юридична наука озброює науковців такими термінами як «цілі», «завдання», «повноваження», «результат правового регулювання» тощо, але, не дивлячись на це, постійно звертається до категорії «функція» та через іiі використання намагається пояснити «призначення»: а) держави в цілому, та окремих державних органів, зокрема; б) права як соціального регулятора та окремих його елементів; б) інших державно-правових явищ, які є розповсюдженими у реальному житті (наприклад, юридичної науки, юридичної відповідальності, нормативно-правового акту).

Не $\epsilon$ виключенням в цьому сенсі і адміністративний процес, функції якого фрагментарно досліджені в науці адміністративного права. Проте відсутнє чітке уявлення про підстави використання цього терміну в наукових джерелах та джерелах права. У зв'язку з цим важливим $\epsilon$ аналіз основних підходів до визначення поняття «функції», яке використовується у наукових працях та чинному законодавстві.

Постановка завдання. Загальні підходи до визначення поняття «функція» та обгрунтування функцій адміністративного процесу розкривається у працях В.Б. Авер'янова, В.М. Бевзенко, Ю.П. Битяка, А.С. Васильєва, Т.О. Коломоєць, О.В. Кузьменко, Є.В. Курінного, П.С. Лютікова, О.М. Миколенко, Ю.В. Пирожкової, С.Г. Стеценка, В.А. Юсупова та інших вчених. Навіть у тих випадках, коли науковці сходяться у визначенні функцій держави, права чи будь-якого іншого державно-правового явища, вони завжди пропонують свій набір функцій, які, на їх думку, розкривають призначення цього явища у державі та національному праві. «Функція» як категорія юридичної науки є результатом наукової абстракції, а тому посмакувати, доторкнутися, побачити або іншим чином відчути іiї в реальному житті неможливо. Однак, за наявності певних змін в суспільстві можна стверджувати про іiі існування і реалізацію. Скільки дослідників займаються цією проблематикою, стільки і уявлень про функції держави, права та юридичного процесу.

Отже, огляд основних видів наукових підходів до категорії «функція» є важливим для розуміння адміністративного процесу та його функціонального призначення у правовій системі України.

Основними завданнями, розв'язанню яких присвячена ця стаття, є наступні:

1) означити основні наукові підходи до визначення поняття «функція»;

2) охарактеризувати особливості кожної із представлених в науковій літературі концепцій визначення змісту поняття «функція».

Результати дослідження. Аналіз наукової літератури дає можливість виділити наступні підходи до визначення поняття «функція».

1. Функцію державно-правового явища дуже часто розглядають як призначення, роль когочи чого-небудь. Наприклад, В.О. Козбаненко зазначає, що під функціями державного управління слід розуміти роль, яку виконує державний апарат (керуюча система держави або ії елементи) для того, щоб спонукати, направити, організувати суспільну життєдіяльність (керовані державою об'єкти), впливати на неї для досягнення поставлених цілей [1, с. 28]. Подібний підхід використав і М.М. Марченко при визначенні функцій правопорядку. Так, зазначається, що функції правопорядку це та роль, яку правопорядок виконує в правовій системі суспільства, в державному конституційному порядку, в режимі демократії [2, с. 199-200]. Разом з тим, такий підхід дає лише загальне уявлення про функцію як категорію юридичної науки, адже, при цьому, не пропонується методика визначення «ролі» державно-правового явища. Тобто визначення функцій відбувається на інтуїтивному рівні без залучення науково-методологічної основи. Якщо подібний підхід 
використати до функцій адміністративного процесу, то прийти можна як до простих висновків, коли адміністративний процес буде виконувати лише одну правоохоронну функцію, а можна $\mathrm{i}$ до більш складних висновків, коли адміністративний процес буде виконувати декілька основних функцій, наприклад, контрольну, охоронну та захисну. Разом з тим, ці висновки не будуть науково обгрунтованими, адже вони зроблені не на підставі наукового аналізу, а лише на підставі внутрішнього сприйняття ролі адміністративного процесу в сучасній правовій системі України.

2. Функцію державно-правового явища дуже часто розглядають як роботу кого-, чого-небудь, обов'язок, коло діяльності. Поширеним такий підхід є в національному законодавстві. Наприклад, Закон України «Про дипломатичну службу» до основних функцій дипломатичної служби відносить: 1) здійснення зовнішньополітичної діяльності держави; 2) організацію проведення переговорів, а також участь у підготовці укладення міжнародних договорів України; 3) підготовку пропозицій щодо вдосконалення законодавства України у сфері міжнародних відносин; 4) забезпечення в установленому порядку зберігання міжнародних договорів України; 5) поширення інформації про Україну за кордоном та багато інших функцій [3]. Стаття 2 Закону України «Про прокуратуру» дає наступний перелік функцій прокуратури: 1) підтримання державного обвинувачення в суді; 2) представництво інтересів громадянина або держави в суді у випадках, визначених законодавством; 3 ) нагляд за додержанням законів органами, що провадять оперативно-розшукову діяльність, дізнання, досудове слідство; 4) нагляд за додержанням законів при виконанні судових рішень у кримінальних справах, а також при застосуванні інших заходів примусового характеру, пов'язаних з обмеженням особистої свободи громадян [4]. Якщо зводити функції лише до переліку основних видів робіт, що виконує орган, установа, підприємство чи організація, то це дасть лише часткове уявлення про його взаємодію із зовнішнім середовищем, але не дасть відповіді на питання про достатність здійснюваних функцій, а тим паче про якість та ефективність ïx виконання. Тобто такий підхід до поняття функція дає можливість лише констатувати певні факти дійсності (наприклад, вчора цю функцію реалізовував один орган, а сьогодні вже інший), але не дає можливості оцінити критерії розподілу функцій в системі органів державної влади та доречність виконання конкретної функції одним із органів державної влади.

3. Часто функцію державно-правового явища розглядають в юридичній літературі як напрям дії кого- чи чого-небудь. Наприклад, Ю.М. Обротов пропонує визначати функції держави як основні напрямки діяльності держави [5, с. 141], а С.Л. Лисенков визначає функцію права як основні напрями його впливу на суспільні відносини [6, с. 136]. Як бачимо, йдеться не про діяльність чи вплив державно-правових явищ, а лише про напрями, за якими така діяльність і вплив здійснюються. Якщо ця концепція частково спрацьовує при характеристиці, наприклад, органів державної влади чи галузей права, то при визначенні функцій адміністративного процесу, важко буде визначитись з напрямами. Наприклад, якщо взяти за основу визначення судового процесу, яке дається в ст. 4 КАСУ: «судовий процес - правовідносини, що складаються під час здійснення адміністративного судочинства», то виникає доречне питання - які напрямки можуть мати правовідносини? На жаль, цей підхід до визначення функцій є домінуючим в юридичній науці та праві. Навіть у сучасних дослідженнях правових явищ наголошується на функціях як напрямках діяльності чи впливу. Наприклад, Н.В. Іванюта в монографії 2018 року зазначає: «Функції господарського процесуального права це певні напрямки впливу господарських процесуальних норм, обумовлених суспільними відносинами з вирішення господарських спорів та інших правових питань, які в результаті забезпечення функціональних зв'язків між об'єктами господарського процесуального права та іншими його правовими компонентами спрямовані на певний результат в межах здійснення справедливого судового захисту порушених, невизнаних або оспорюваних прав і охоронюваних законом інтересів фізичних та юридичних осіб» [7, с. 33]. По-перше, визначення, запропоноване Н.В. Іванютою, є занадто громіздким. Автор намагається охопити в межах одного визначення все - і специфіку об'єкта правового регулювання, і принципи судочинства, $\mathrm{i}$ інтереси фізичних та юридичних осіб, які захищаються в межах судового провадження. Маючи об’єм, визначення позбавлене конкретики стосовно самого змісту функцій. По-друге, у визначенні відбулося ототожнення функцій господарського процесуального права як цілісної системи i функцій господарських процесуальних норм, як одного із найменших елементів цієї системи. Переконані в тому, що необхідно враховувати відмінності, що існують між функціями галузі права та функціями окремої правової норми.

4. В сучасних публікаціях з'явилися тенденції негативного сприйняття поняття функція. Наприклад, I.C. Канзафарова заперечує доцільність використання в наукових працях та джерелах права поняття «функція», вважаючи, що його без перешкод можна замінити на три самостійних 
поняття - цілі, засоби і результат. Використання ж цього терміну в наукових працях лише відволікає від сутності правових явищ [8, с. 25]. Так радикально вирішувати долю наукової термінології не потрібно. Поняття «функція» дійсно має сфери обгрунтованого використання. Науковій спільноті лише слід запропонувати чіткі критерії щодо визначення іiї змісту, стосовно сфер ії використання як категорії адміністративного права і процесу, а також стосовно методологічних властивостей.

5. Новою для національної юридичної науки є концепція функцій, яку запропонувала О.М. Миколенко. Вчена намагалася, по-перше, переглянути традиційні уявлення про функції в юридичній науці, по-друге, вивести вчення про функцію на практично-прикладний рівень. На відміну від І.С. Канзафарової, О.М. Миколенко запропонувала розглядати поняття «функція» як симбіоз трьох понять «цілі», «засоби» і «результат». Це дозволило, по-перше, встановити існуючі взаємозв'язки і взаємовплив кожного із зазначених елементів, по-друге, визначитись з критеріями ефективності та якості реалізації функцій та, по-третє, виявити недоліки в правовому регулюванні і запропонувати шляхи їх вирішення [9, с. 266-301].

6. Останній науковий підхід до визначення поняття «функція», який заслуговує уваги, це функціональний підхід, який пропонує в своїх працях Р. Мертон. В одній із своїх праць, Р. Мертон зазначає, що провідними постулатами функціонального підходу є наступні [10, с. 238]:

1) функціональна єдність цілого, тобто кожен елемент системи забезпечує ефективне та якісне функціонування системи в цілому;

2) універсальний функціоналізм вимагає відповідність елементів системи тим функціям, які реалізує система в цілому;

3) функціональна необхідність, тобто система в цілому та ії елементи зокрема, повинні реалізовувати лише ті функції, які дозволяють системі ефективно існувати (а в певних випадках виживати);

4) універсальність функціоналізму, тобто взаємозамінність елементів в кризових ситуаціях, коли з об'єктивних причин один із елементів не може виконувати тимчасово або на постійній основі свої функції;

5) примусовість, без якої не можлива взаємодія елементів системи.

Погоджуючись з більшістю аргументів Р. Мертона, автор зазначає наступне:

по-перше, примусовість, як постулат функціонального підходу, спрацьовує лише в системах, де елементами системи виступають індивіди чи їх об’єднання. Якщо йдется, наприклад, про функції норми права, людського організму чи адміністративного процесу, то примусовість втрачає обов'язкове значення;

по-друге, універсальність функціоналізму як постулат функціонального підходу теж важко застосувати до функцій адміністративного процесу. Він має місце в системі органів державної влади (орган ліквідовано, а його функції став виконувати інший орган), при характеристиці особливостей функціонування людського організму (у зв’язку з ампутацією правої руки іiї функції почала виконувати ліва рука), при обгрунтуванні певних антисоціальних явищ у суспільстві (на місце одного злочинного угрупування прийшло інше, адже функція, яку воно виконувало, нікуди не ділась). Разом з тим, відносно функцій адміністративного процесу цей постулат, як правило, не спрацьовує. Наприклад, самовідвід судді можна було б розглядати як механізм взаємозамінності суб'єктів адміністративного процесу в кризових ситуаціях, але суддя не є елементом структури адміністративного процесу;

по-третє, функціональна єдність цілого, як постулат функціонального підходу, може бути застосований і при аналізі функцій адміністративного процесу. Адміністративний процес можна розглядати як системне явище, він складається з проваджень, стадій, етапів та окремих процесуальних дій. Кожен елемент цієї системи забезпечує ефективне та якісне функціонування адміністративного процесу в цілому;

по-четверте, при аналізі особливостей функцій адміністративного процесу можна використовувати і універсальний функціоналізм, як другий постулат функціонального підходу. Тобто кожен елемент системи (в нашому випадку вид провадження чи стадія адміністративного судочинства) повинен відповідати тим функціям, які реалізує адміністративний процес в цілому. Наприклад, спрощені позовні провадження не повинні заважати реалізації таких загальних функцій адміністративного процесу як охорона, контроль та захист;

по-п’яте, реалізація функціональної необхідності, як третього постулату функціонального підходу, при визначенні функцій адміністративного процесу проявляється в тому, що адміністративний процес в цілому та окремі його елементи повинні реалізовувати лише ті функції, які дозволяють системі досягати поставлених цілей. 
Висновки. На підставі проведеного дослідження можна зробити наступні висновки.

1. Аналіз наукової літератури дає можливість виділити наступні основні підходи до визначення поняття «функція»: 1) функція як призначення, роль кого- чи чого-небудь; 2) функція як робота кого-, чого-небудь, обов'язок, коло діяльності; 3) функція як напрям дії кого- чи чого-небудь; 4) повна відмова від використання поняття в наукових джерелах та джерелах права; 5) функція як симбіоз трьох понять «цілі», «засоби» і «результат»; 6) дослідження функцій через застосування постулатів функціонального підходу.

2. Функціональна єдність цілого, як постулат функціонального підходу, може бути застосований і при аналізі функцій адміністративного процесу. Адміністративний процес можна розглядати як системне явище, він складається з проваджень, стадій, етапів та окремих процесуальних дій. Кожен елемент цієї системи забезпечує ефективне та якісне функціонування адміністративного процесу в цілому.

3. При аналізі особливостей функцій адміністративного процесу можна використовувати і універсальний функціоналізм, як другий постулат функціонального підходу. Тобто кожен елемент системи (в нашому випадку вид провадження чи стадія адміністративного судочинства) повинен відповідати тим функціям, які реалізує адміністративний процес в цілому. Наприклад, спрощені позовні провадження не повинні заважати реалізації таких загальних функцій адміністративного процесу як охорона, контроль та захист.

4. Реалізація функціональної необхідності, як третього постулату функціонального підходу, при визначенні функцій адміністративного процесу проявляється в тому, що адміністративний процес в цілому та окремі його елементи повинні реалізовувати лише ті функції, які дозволяють системі досягати поставлених цілей.

\section{Список використаних джерел:}

1. Государственное управление: основы теории и организации: учебник в 2 т. Т. 2. $/$ Е.В. Волкова, А.И. Гаврилов, В.И. Галактионов, В.А. Козбаненко и др.; под ред. В.А. Козбаненко. Изд. 2-е, с изм. и доп. Москва : Статут, 2002. 592 с.

2. Общая теория государства и права. Академический курс в 3-х томах. Том 2 / В.В. Борисов, Н.В. Витрук, Н.Л. Гранат, В.П. Казимирчук и др.; отв. ред. М.Н. Марченко. Изд. 2-е, перераб. и доп. Москва : ИКД «Зерцало-М», 2002. 528 с.

3. Про дипломатичну службу: Закон України від 07.06.2018 р. Відомості Верховної Ради, 2018, № 26, Ст. 219. Ст. 12 .

4. Про прокуратуру: Закон України від 14.10.2014. Відомості Верховної Ради. 2015. № 2-3.

5. Оборотов Ю.Н. Теория государства и права (прагматический курс): Экзаменационный справочник. Одесса : Юридическая литература, 2006. 184 с.

6. Теорія держави і права: навчальний посібник / А.М. Колодій, В.В. Копєйчиков, С.Л. Лисенков та ін.; за заг. ред. С.Л. Лисенкова, В.В. Копєйчикова. Київ : Юрінком Інтер, 2004. 368 с.

7. Іванюта Н.В. Функції господарського процесуального права: теоретико-практичні аспекти : монографія. Одеса : Фенікс, 2018. 516 с. $264 \mathrm{c}$.

8. Канзафарова І.С. Теорія цивільно-правової відповідальності. Одеса : Астропрінт, 2006.

9. Миколенко О.М. Функції адміністративно-деліктного права (теоретико-правовий аспект): дис. ...док-ра. юрид. наук: 12.00.07 - адміністративне право і процес; фінансове право; інформаційне право. Запорізький національний університет, Запоріжжя, 2018. 484 с.

10. Мертон Р. Создание парадигмы структурного функционализма в версии теории среднего уровня. URL: http://ecsocman.hse.ru/data/337/641/1219/t15.pdf (дата звернення: 01.07.2019). 